\title{
AIDS REVIEW: Women and Health in Africa
}

\author{
Alice Henry
}

Women and Health in Africa, edited by Meredith Turshen, Africa World Press, Inc., PO Box 1892, Trenton NJ 08607, 1991. US\$14.95 ISBN 0865431817

Meredith Turshen has collected articles reflecting the complex health problems of African women within the broad context of war and revolution, economic and work issues, and population growth as well as looking at 'just' health, and health programmes. Many of the articles are based on field research done by African people (some men) now writing or studying abroad. Here is a report on just one, but an exemplary one.

'Gender, Power and Risk of AIDS in Zaire' is a report on a CONNAISSIDA action research by Brooke Grundfest Schoepf, Walu Engundu, Rukarangira Wa Nkera and Claude Schoepf. CONNAISSIDA was set up to understand how AIDS affects the people of Kinshasa and Lumumbashi, Zaire's two largest cities with a combined population of more than four and one-half million, and the causes, including cultural ones, which affect the spread of infection.

In Zaire, and the rest of Africa, AIDS is primarily transmitted by heterosexual sex. Contamination of the blood supply is another important factor, especially affecting women because blood transfusion after illegal abortion is all too common. In 1986, infection levels were reported to be between 6 and 9 per cent among sexually active urban adults, but in some East African cities up to 30 per cent test positive for HIV. In this situation, prevention involves convincing everyone that 'normal', 'natural', everyday patterns of sexual behaviour must change. Unfortunately, there is nowhere in the world where knowing the facts is enough to change sexual behaviour. By mid-1987 almost all of six hundred adults and teenagers interviewed understood AIDS to be a fatal disease, transmitted by sexual relations and exchange of blood. But one fact that

Feminist Review No 41, Summer 1992 
could help change behaviour was missing; most did not know what a condom was.

The authors point out that disease epidemics often erupt in times of war, and economic crisis certainly makes public health measures against spread of disease difficult. Zaire has been hit by bad international trade conditions and a heavy burden of debt. Since publication of the article, rebellion against Mobutu's rule has hit the headlines, leading even the US to question his dictatorial methods.

The authors go on to say that women have a particularly hard time economically, although men too find few paid jobs in the recorded economy. Most women were and are confined to raising crops and children; when they move to cities they support themselves through petty trade and services - food preparation, sewing, smuggling, making beer and alcohol, and sexual services.

Some of the complexity of sexual exchanges are captured by the authors:

Several forms of stable multiple partnerships are linked to informal sector activities and may contribute to the spread of AIDS. For example, male long distance traders are likely to have several wives or women with whom they live in relatively stable unions in towns along their routes. Wives and children provide the trader with an identity as a responsible adult with a reason for being in the town. Wives make trading contacts and obtain permits using their local kinship and patron-client networks. They also may trade on their own account with goods or capital supplied by the visiting husband. Some wives are monogamous; others have two or more husbands.

Women traders are perceived by many men as universally promiscuous. Since they are able to command their own resources, their sexuality is beyond male control. Women who are not deterred by moral scruples can use sexual strategies to economic advantage. Some develop regular sexual relationships with officials to facilitate obtaining permits and fee waivers.

In fact, it's risky to engage in any irregular trade unless you have political protection.

It's no surprise to find that sex and living arrangements are thoroughly entangled with economic exchanges and mutual support. It would be ridiculous to try to stop sexual trading in Zaire or anywhere else, so instead, CONNAISSIDA looked at how to overcome the constraints that make condom use difficult.

Their first workshops, addressed to women living in a low-income community, used role play, group discussion and other active learning methods to show women they could reduce the risk of getting AIDS. In October 1987, a network of fifteen sex workers asked CONNAISSIDA for information on how to prevent AIDS. The women had known for some time that their activities put them at risk, but they had no other way to support themselves so felt they couldn't do anything about it. But 
recently their neighbours had begun to make hostile comments about them being 'disease distributors' - a result of the national mass-media campaign.

The examples of how the sessions were run might help other AIDS educators. They included other community-health issues related to AIDS to defuse the stigma attached to sexual transmission, talking about ways to prevent malaria so fewer anaemic children would need blood transfusions. They explained how needles should be sterilized, or thrown away if they're the disposable type. Although drug injection isn't a common way of transmitting AIDs in Zaire, hospital transfusions are, and this demonstration gave the women a way to check on hygiene standards at their local dispensary.

They held a whole session on condoms, trying to make women comfortable with a largely uncongenial, unnatural and foreign technology. They put condoms on cola bottles, broke a few, and talked about how to get them on the men. They then took some home so they could bring back reports on success and failure.

The local Protestant Mothers Club learned about the workshops for sex workers and asked CONNAISSIDA to hold some workshops for them. This also involved 'condom seduction', expertly performed by a grandmother who used to be a professional sex worker, playing the reluctant husband, and a young sex worker, a member of the congregation, who played the cajoling wife. This wasn't a set-up by the project workers; in fact, it brought home to them the fluidity between 'prostitutes', 'mothers' and 'church members'.

Follow-ups three months after the sessions found that all but one of the sex workers were using condoms. (The non-user said she had genital sores that made condoms an impossible pain, so the project workers drove her to the hospital for treatment as the local dispensary had no testing facilities.) It seemed that knowing about condoms raised women's prestige; clients liked them knowing about prevention. But six months later, condom use went down from 'almost always' to 'sometimes'. Student clients told them their condoms were outdated; they wanted the more attractive product distributed by the Social Marketing Project. Even worse, Paris Match had run an article by US sex researcher Jonathan Kolodney, who said that condoms are not completely protective. The students thought this meant that condoms were useless, and told the sex workers, 'No need to use those things!' The sex workers didn't want to lose the relatively high-status student customers and hadn't heard any new messages about AIDS. They didn't have radios or TVs, so couldn't hear the message of the Public Health Department's AIDS coordinator who went on TV to promote condoms and the students were inclined to believe the authority of Paris Match.

Women's power relative to men was also an issue for the churchwomen. The husbands of twenty of the sixty participants refused point blank to use condoms or discuss the risk of AIDS. Some husbands with multiple partners were angry and threatening. One husband refused to give his partner the monthly housekeeping allowance and 
told her to go hustle for it. Another twenty at least had a discussion with their partner, but were persuaded their risks were minimal. In this group, both partners said they had not had any other partner for the past few years. The last twenty said their husbands agreed, at least in principle, to use condoms. The researchers weren't sure about actual practice, and intended to find some way of getting anonymous selfreports.

There were several other reactions that would also slow the spread of AIDS. The churchwomen asked for workshops for husbands and young adults in their households, showing that young people can be reached through their family, even if older family members aren't happy directly talking about sex issues with the younger set.

Both sex workers and women in the church group asked for help in getting treatment for symptoms of sexually transmitted disease. Genital ulcers help the spread of AIDS; there were no treatment facilities close by. There seemed to be little chance of opening a clinic; the project provided transportation to the nearest centre.

The groups agreed that what women most needed were ways to make money so they didn't have to depend on men and have to provide sexual services to multiple men in order to survive. The women had tried many ways to enlarge their family resources, but with little luck. They had not yet come up with a realistic plan of cooperative action.

The massive resistance to practical responses is illustrated by the following example. The church mothers club organized a banquet for participants and health trainers; the minister spoke, informing them that AIDS is divine retribution for sins; the righteous need not fear infection. The Protestant bishop had also recently mouthed similar platitudes.

CONNAISSIDA concludes that women cannot effect change all by themselves; surely just distributing condoms to sex workers (a government suggestion) will have little impact in a situation where 10 to 30 per cent of sexually active men and women test positive for HIV. They suggest that men, especially high-status men, have to change their ways.

Culturally appropriate empowering education is one necessary but not sufficient part of AIDS prevention, or of any health and development strategy. The limited long-term success of CONNAISSIDA's experiment with sex workers and churchwomen is a reminder that communication systems are social systems and exhibit the same hierarchically structured patterns as the wider society.

Exactly. AIDS control means increasing the economic and social status of women, and not even a brilliant action-research programme like CONNAISSIDA can do that. Nevertheless, Brooke Schoepf and her co-authors give a good model of how to report the specifics of AIDS intervention, and several of their actions can give ideas to AIDS activists in any country. 